University of Nebraska - Lincoln

DigitalCommons@University of Nebraska - Lincoln

Papers in the Earth and Atmospheric Sciences

Earth and Atmospheric Sciences, Department

\title{
Modern and Late Holocene Wind Regimes over the Great Plains (Central U.S.A.)
}

\author{
Rebecca L. Schmeisser \\ University of Nebraska, Lincoln, rebecca.schmeisser@huskers.unl.edu \\ David B. Loope \\ University of Nebraska, Lincoln, dloope1@unl.edu \\ Joseph A. Mason \\ University of Wisconsin, Madison, mason@geography.wisc.edu
}

Follow this and additional works at: https://digitalcommons.unl.edu/geosciencefacpub

Part of the Earth Sciences Commons

Schmeisser, Rebecca L.; Loope, David B.; and Mason, Joseph A., "Modern and Late Holocene Wind Regimes over the Great Plains (Central U.S.A.)" (2010). Papers in the Earth and Atmospheric Sciences. 252.

https://digitalcommons.unl.edu/geosciencefacpub/252

This Article is brought to you for free and open access by the Earth and Atmospheric Sciences, Department of at DigitalCommons@University of Nebraska - Lincoln. It has been accepted for inclusion in Papers in the Earth and Atmospheric Sciences by an authorized administrator of DigitalCommons@University of Nebraska - Lincoln. 


\title{
Modern and Late Holocene Wind Regimes over the Great Plains (Central U.S.A.)
}

\author{
Rebecca L. Schmeisser \\ Department of Geosciences, 214 Bessey Hall, University of Nebraska, Lincoln, NE 68588, USA \\ [Corresponding author - tel./ fax 402 472-2663, email rebecca.schmeisser@huskers.unl.edu ] \\ David B. Loope \\ Department of Geosciences, 214 Bessey Hall, University of Nebraska, Lincoln, NE 68588, USA; dloope1@unl.edu \\ Joseph A. Mason \\ Department of Geography, 207 Science Hall, 550 North Park Street, \\ University of Wisconsin, Madison, WI 53706, USA; mason@geography.wisc.edu
}

\begin{abstract}
The Great Plains of the central United States contain numerous presently stabilized dune fields that were active during the late Holocene. The most recent period of reactivation occurred about 700-1000 years ago during the Medieval Climatic Anomaly, a period of frequent, severe drought recognized throughout the North American West. Dune orientations and internal bedding preserve information about paleowinds from this time period. We compared paleowind information with modern winds and potential sand transport analyzed from meteorological data. While both reconstructed paleowinds and modern winds include a strong northwesterly component over the northern to central portions of the Great Plains, a significant difference exists to the south. During the late Holocene, southwesterly winds had a strong influence on dune forms over the central and southern Great Plains, while modern potential sand transport is dominated by southerly to southeasterly winds that bring moisture to the region from the Gulf of Mexico. Hypothetical dune types forming under modern winds would be different and have different crestal orientations than those preserved from the late Holocene. In order for such a shift in southerly winds to take place it is likely that: 1) the typical position of the Bermuda High in summer was shifted either to the east or to the south resulting in weaker low-level winds from the south and southeast and greater extent of southwesterly winds on the Great Plains, and/or 2) drought, likely enhanced by evapotranspiration and soil moisture feedbacks, brought the normally higherlevel southwesterly flow down to the land surface. Given our understanding of megadroughts over the Great Plains as well as recent climate predictions for increased warmth and drought over this area, future reactivation of the dunes seems likely.
\end{abstract}

\section{Introduction}

The Great Plains of North America is covered with numerous dune fields that have been active during the Holocene. Within the United States, the dune fields occur sporadically across an area from North Dakota to parts of Texas and from the eastern part of Colorado to eastern Nebraska (Figure 1). These dune fields serve as an indicator of past decades to millennia of frequent, severe drought in the region. Presently, nearly all of these dunes are stabilized and are part of large grassland ecosystems. The productivity of the vegetative cover correlates strongly with the west to east gradient in precipitation over the central United States, with greater amounts of precipitation to the east. There is also a strong north to south temperature gradient across the region, with warmer temperatures to the south (National Map, 2009).

The goal of this study is to gain an understanding of how winds have shifted over the Great Plains since the last major dune reactivation (1050-650 years B.P.). Past directions of sand-transporting winds are preserved in dune orientations and internal structures while meteorological stations from the last few decades record detailed information about the strength and direction of modern winds. We use these two records of winds across the Great Plains to examine if and how winds have changed from a time of significant drought (the Medieval Climatic Anomaly) to a time of relatively high moisture (the present). This information may help to explain how the dunes have reactivated in the past. This is particularly important given the consensus of recent modeling studies that show that temperatures will rise substantially and summer precipitation may decrease across the Great Plains over the next century (Christensen et al., 2007), increasing the likelihood of drought during the growing season.

\section{Previous work}

Early studies concluded that the dune fields across the Great Plains formed and were active mainly during the Pleistocene, 


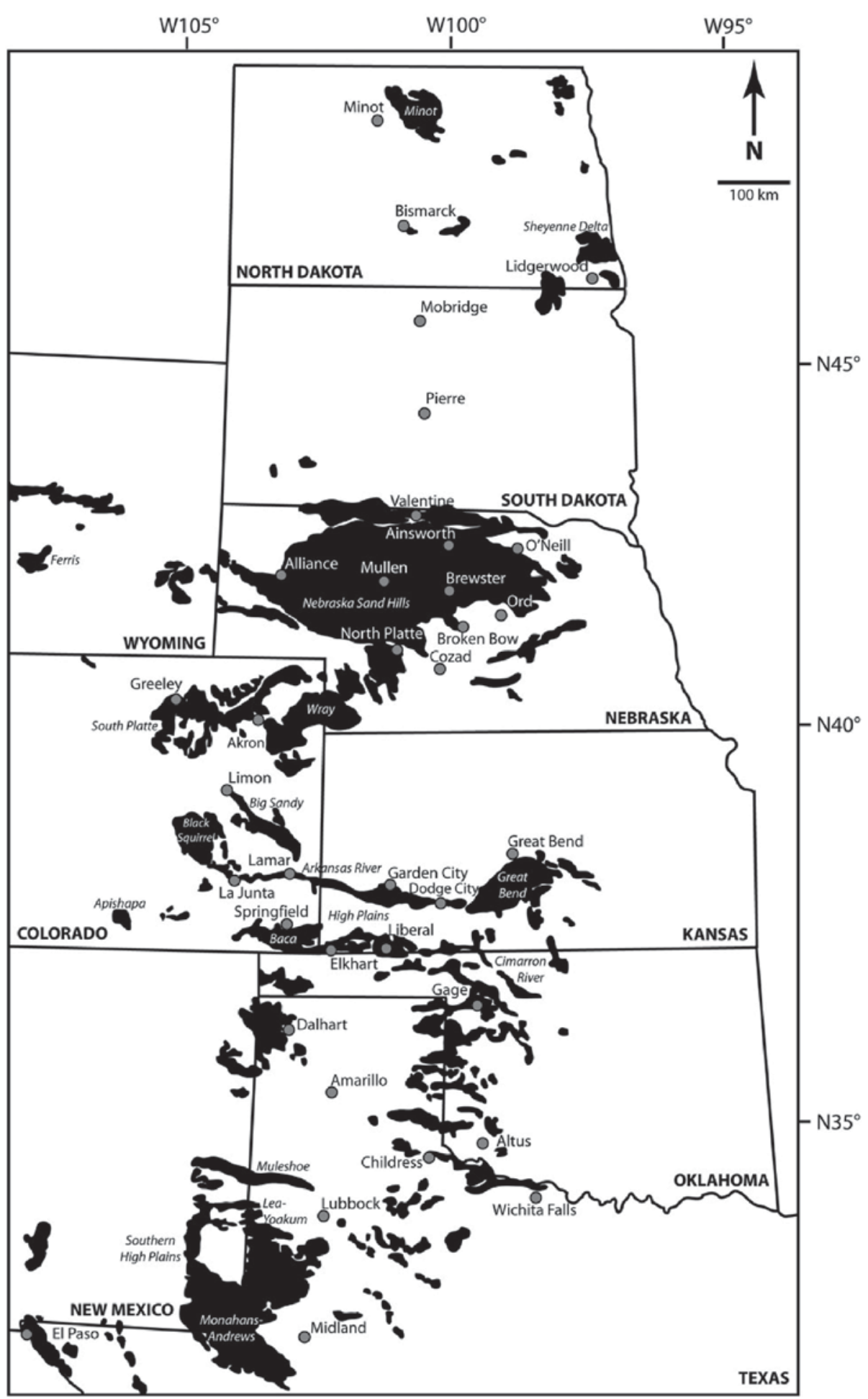

Figure 1. Map of Great Plains dune fields (black shading, after Muhs and Holliday (1995)-central and southern Great Plains and Muhs and Wolfe (1999)-northern Great Plains) and station locations (gray-filled circles). Dune field names are given in italics.

under cool and dry glacial conditions (Smith, 1965; Watts and Wright, 1966; Warren, 1976; Sarnthein, 1978; Wells, 1983; Kutzbach and Wright, 1985). More recent radiocarbon and luminescence dating of the dunes throughout the region have shown that while the dunes may have initially formed during the Pleistocene, major dune activity occurred periodically throughout the Holocene (Ahlbrandt et al., 1983; Holliday, 1991, 2001; Madole, 1995; Arbogast, 1996; Muhs et al., 1996, 1997a; Stokes and Swinehart, 1997; Loope and Swine- hart, 2000; Forman et al., 2001; Clarke and Rendell, 2003; Goble et al., 2004; Miao et al., 2007).

During the transition from the Pleistocene to the Holocene, about 11,500 calendar years ago, the ice sheets retreated as climate rapidly warmed, but the Great Plains remained fairly dry (Ahlbrandt et al., 1983). Widespread dune mobilization has been recognized following this transition, from about 9000 to 4500 years ago (Arbogast and Johnson, 1998; Forman et al., 2001; Holliday, 2001; Miao et al., 2007). Since approxi- 
mately 5000 years ago, dune movement has been highly variable, with a number of discrete dry events throughout the region (Madole, 1994; Arbogast and Johnson, 1998; Muhs and Wolfe, 1999; Forman et al., 2001; Holliday, 2001; Lepper and Scott, 2005; Miao et al., 2007).

The most recent period of full dune reactivation (the Medieval Climatic Anomaly) is recognized in dune fields across the Great Plains from approximately 1050-650 years B.P. This event coincides with the Medieval Warm Period, a period of warm and variable climate recognized in Europe (Cook et al., 2004). This extended drought has been documented within North America using several types of proxies including lake levels and salinity, tree ring records (Cook et al., 2004), and timing of dune activity (Mason et al., 2004, 2007). Smaller, more recent droughts are recognized in some dune fields in the Great Plains (Clarke and Rendell, 2003; Forman et al., 2005, 2008), although these events were not extensive enough to promote complete dune reactivation across the area (Muhs and Holliday, 1995; Wolfe et al., 2001). These small periods of dune activity are recognized in single dune fields, suggesting localized drought (rather than regional drought, as in the Medieval Climatic Anomaly).

The episodes of drought recognized in the Great Plains have been dated using two main methods. First, organic material gathered from paleosols found within the dunes has been dated using the radiocarbon method (Ahlbrandt et al., 1983; Forman and Maat, 1990; Arbogast and Johnson, 1998; Holliday, 2001; Lepper and Scott, 2005). These dates provide limiting ages for sand layers present above or below the organic material. More recently, luminescence geochronology, typically optically stimulated luminescence, has been used to date the eolian sands themselves (Forman and Maat, 1990; Goble et al., 2004; Lepper and Scott, 2005; Miao et al., 2007; Forman et al., 2008), providing specific information about periods of dune movement.

\section{Dune types and dune crest orientations}

Dunes are classified in two main ways, morphologically and morphodynamically. Dune types based on morphology include crescentic dunes, dome dunes, parabolic dunes, linear dunes, and star dunes. Crescentic dunes are asymmetric dunes with sinuous crestlines typically oriented perpendicular to the wind and include barchan dunes and transverse or crescentic ridges. Barchan dunes typically occur in regions with low sediment supply while transverse ridges typically occur in regions with abundant sediment. Dome dunes are classified as circular to elliptical dunes without slipfaces. Some dome dunes may be remnants of star dunes. Parabolic dunes are considered to be deflation features and occur in areas of sparse vegetation. These dunes are U-shaped with the arms anchored and the noses pointing downwind. Linear dunes are symmetrical with sinuous to straight crestlines and slipfaces on both sides. Finally, star dunes are classified as multi-armed dunes with multiple slipfaces and crestlines (McKee, 1979; Kocurek, 1996).

The morphodynamic classification of dunes divides elongate dunes into three categories based on the angle between the orientation of the dune crestline and the resultant sand transport direction. Longitudinal dunes have crests oriented nearly parallel $\left(0-15^{\circ}\right)$ to the resultant sand transport direction. Crests of transverse dunes are oriented nearly perpendicular $\left(75-90^{\circ}\right)$ to the resultant sand transport direction. Oblique dunes have crests oriented at an angle $\left(15-75^{\circ}\right)$ to the resultant sand transport direction (Hunter et al., 1983).

The classification of dunes is particularly important when examining their response to various wind regimes (Fryberger, 1979). Unimodal wind regimes are those with a single peak or mode, with the majority of the drift potential for an area oc- curring in the same general direction. Transverse, barchanoid, and barchan dunes form under these conditions and are oriented roughly perpendicular to the resultant drift direction. Wind regimes with two peak distributions of drift potential are called bimodal wind regimes. Linear dunes typically form under bimodal wind regimes. Finally, complex wind regimes have greater than two peak distributions of drift potential and typically form star dunes.

\section{Methods}

The morphology, orientation, and internal structures of stabilized dunes reflect the wind direction(s) from the last time the dunes were mobile. We made interpretations of ancient wind directions from dune fields in North Dakota, Nebraska, Colorado, Kansas, Oklahoma, and Texas from the literature. Those studies use dune orientations and dune type to obtain paleowind information. Internal structures were also used in several studies. Additional paleowind information from the Nebraska Sand Hills was obtained by measuring internal structures in dunes at several locations throughout the dune field.

We studied modern winds across the Great Plains using data on wind direction and speed from 35 modern meteorological stations. The data were compiled into a series of sand roses, circular histograms which graphically represent an index of potential sand transport that can occur in a given time (the drift potential) for all directions (Fryberger, 1979). The lengths of the arms on a sand rose are proportional to the drift potential, which is given in vector units. The following equation was used to calculate the drift potential $(Q)$ for each direction: $Q=V^{2}$ $\left(V-V_{t}\right) t$, where $V=$ the velocity of wind as measured at $10 \mathrm{~m}$ height, $V_{\mathrm{t}}=$ the impact threshold wind velocity for sand with a mean diameter of $0.25-0.30 \mathrm{~mm}$ at a $10 \mathrm{~m}$ height, given as $6 \mathrm{~m} / \mathrm{s}$ in this study, and $t=$ the amount of time the wind blew given as a percentage (Fryberger, 1979). The drift potential for every $10^{\circ}$ around $360^{\circ}$ was calculated for each station and results were compiled to create a sand rose. Annual and seasonal roses were compiled for each station, with spring defined as March through May, summer defined as June through August, fall defined as September through November, and winter defined as December through February. The resultant drift direction (RDD) for each rose was calculated as the vector sum of drift potentials for individual directions. The RDD gives the hypothetical net direction that sand would move over time. The resultant drift potential (RDP) was also calculated for each rose and is the magnitude of the RDD or the net potential for sand movement, and is given in vector units (Fryberger, 1979). Hypothetical dune orientations were calculated using a modified version of the program Trend (Rubin and Ikeda, 1990; Lancaster et al., 2002; Sridhar et al., 2006). Dune type was determined by taking the angle between the calculated hypothetical dune orientation and RDD and using the morphodynamic classification of dunes as defined by Hunter et al. (1983).

Sand roses were compiled for a total of 35 stations spaced throughout the Great Plains in or near ancient dune fields in North Dakota, Nebraska, Colorado, Kansas, Oklahoma, and Texas (Table 1). Two of the 35 stations are located in South Dakota and are not near ancient dune fields, but provide necessary information between the North Dakota and Nebraska sites. Where possible, the last 35 years of data (1973-2007) were used to compile sand roses, however data from this duration were not available for all stations (Table 1).

\section{Late Holocene dune fields and wind directions}

Ancient wind directions have been interpreted by previous researchers within dune fields throughout the Great Plains (Muhs 
Table 1. Station locations used in the study, including years of data available, hypothetical modern resultant drift direction (RDD), resultant drift potential (RDP), and dune orientation.

\begin{tabular}{|c|c|c|c|c|c|}
\hline Station name & State & Years of data & RDD & RDP & Dune orientation \\
\hline Minot & North Dakota & 1973-2007 & 117 & 65 & 33 \\
\hline Bismarck & North Dakota & $1973-2007$ & 134 & 54 & 47 \\
\hline Lidgerwood & North Dakota & 1984-95 & 53 & 12 & 27 \\
\hline Mobridge & South Dakota & $1973-2007$ & 160 & 52 & 53 \\
\hline Pierre & South Dakota & 1973-2007 & 144 & 80 & 45 \\
\hline Valentine & Nebraska & $1973-2007$ & 102 & 56 & 65 \\
\hline Ainsworth & Nebraska & 1973-2007 & 103 & 90 & 69 \\
\hline $\mathrm{O}^{\prime}$ Neill & Nebraska & $1984-90,96-2007$ & 124 & 102 & 61 \\
\hline Alliance & Nebraska & 1973-2007 & 115 & 85 & 52 \\
\hline Mullen & Nebraska & $1973-94$ & 129 & 106 & 62 \\
\hline Brewster & Nebraska & 1974-80, 96-2007 & 166 & 72 & 74 \\
\hline Ord & Nebraska & $1982-2007$ & 130 & 94 & 68 \\
\hline Broken Bow & Nebraska & 1973-2007 & 142 & 112 & 67 \\
\hline North Platte & Nebraska & 1973-2007 & 158 & 52 & 66 \\
\hline Cozad & Nebraska & $1986-90$ & 114 & 74 & 67 \\
\hline Greeley & Colorado & $1988-2007$ & 151 & 52 & 57 \\
\hline Akron & Colorado & 1973-2007 & 148 & 69 & 56 \\
\hline Limon & Colorado & $1973-99,2004-07$ & 152 & 62 & 78 \\
\hline Lamar & Colorado & $1975-91,96-2007$ & 36 & 26 & 95 \\
\hline La Junta & Colorado & 1973-2007 & 152 & 55 & 125 \\
\hline Springfield & Colorado & $1999-2007$ & 50 & 97 & 75 \\
\hline Great Bend & Kansas & $1992-2007$ & 20 & 96 & 84 \\
\hline Garden City & Kansas & $1973-2007$ & 139 & 103 & 87 \\
\hline Dodge City & Kansas & $1973-2007$ & 46 & 117 & 87 \\
\hline Liberal & Kansas & $1973-2007$ & 79 & 114 & 96 \\
\hline Elkhart & Kansas & 1993-95, 2003-06 & 1 & 57 & 77 \\
\hline Gage & Oklahoma & $1973-2007$ & 11 & 85 & 88 \\
\hline Altus & Oklahoma & 1973-2007 & 195 & 42 & 88 \\
\hline Dalhart & Texas & 1973-2007 & 92 & 84 & 111 \\
\hline Amanllo & Texas & 1973-2007 & 50 & 101 & 108 \\
\hline Childress & Texas & 1973-2007 & 97 & 63 & 93 \\
\hline Wichita Falls & Texas & $1973-2007$ & 32 & 63 & 81 \\
\hline Lubbock & Texas & $1973-2007$ & 72 & 76 & 114 \\
\hline Midland & Texas & $1973-2007$ & 26 & 61 & 113 \\
\hline El Paso & Texas & $1972-2007$ & 83 & 29 & 172 \\
\hline
\end{tabular}

and Zárate, 2001; Sun and Muhs, 2007). Compiling this information provides a picture of ancient circulation patterns (Figure 2) that can then be compared to modern circulation. Dune fields in this study cover an area from North Dakota to Texas.

Holocene dune fields in North Dakota include the Sheyenne Delta dune field and the Minot dune field (Figure 1). Both are thinner (typically less than $30 \mathrm{~m}$ in thickness; Muhs and Wolfe, 1999) and less extensive than other Great Plains dune fields (Forman et al., 2001). The Minot dune field (Table 2) consists of stabilized dunes and eolian sand sheets. The last major reactivation that affected these dunes occurred about 1000 years ago (Muhs et al., 1997a, 1997b). The sand sheets are low, flat lying features present mainly in the northwestern part of the dune field. Parabolic dunes dominate the remainder of the dune field. The arms of the parabolic dunes trend $\mathrm{N} 45^{\circ} \mathrm{W}$ with the noses pointing to the southeast (Muhs et al., 1997a, 1997b). The dune crests are oriented perpendicular to the paleowinds, southwest-northeast (or $\mathrm{N} 45^{\circ} \mathrm{E}$ ). The dunes thus record the direction of paleowinds from the last period of reactivation as mainly northwesterly (Figure 2; Muhs et al., 1997a, 1997b).

The Nebraska Sand Hills is the largest dune field in North America (Table 2; Ahlbrandt and Fryberger, 1980) and contains dunes up to $135 \mathrm{~m}$ tall (Swinehart, 1998). The sediment within the Sand Hills is mineralogically mature, suggesting that the dunes were likely active during the Pleistocene as well as the Holocene (Muhs et al., 1997a, 1997b). Multiple Holocene reactivations have been recognized using optically stimulated luminescence dating throughout the dune field (Stokes and Swinehart, 1997; Forman et al., 2005; Miao et al., 2007). Major droughts long enough to result in major reactivation of the dunes are centered around $3.8 \mathrm{ka}, 2.5 \mathrm{ka}$, and $0.7 \mathrm{ka}$ (Miao et al., 2007). The latest period of reactivation (the Medieval Climatic Anomaly) spanned from 1050 to 650 years B.P. (Cook et al., 2004). Several less severe droughts have occurred after the Medieval Climatic Anomaly, such as the 1930s Dust Bowl, that have caused increased areas of bare sand and some movement, but not complete reactivation as are seen in the major droughts outlined above (Forman et al., 2005).

There are a variety of dune types and orientations within the Nebraska Sand Hills (Figure 2). In the west-central Sand Hills, the greatly elongated crests of large Pleistocene/Early Holocene barchanoid-ridge dunes lie up to $120 \mathrm{~m}$ above interdune surfaces, and are typically oriented east-west with their steepest slopes facing south (Warren, 1976; Ahlbrandt and Fryberger, 1980; Swinehart, 1998). Further to the west, the crest orientation shifts to become $\mathrm{N} 120^{\circ} \mathrm{W}$. To the east, near the 100th meridian, these dunes are up to $55 \mathrm{~m}$ high and crest orientations are $\mathrm{N} 47^{\circ} \mathrm{W}$. In the western and southwestern portions of the Nebraska Sand Hills, simple and compound parabolic dunes are oriented with the noses of the dunes pointing to the southeast, indicating paleowinds from the northwest. Compound barchan dunes within the western part of the dune field are oriented with slipfaces sloping southeast and east, indicating northwesterly to westerly paleowinds (Swinehart, 1998). Smaller (12-15 m high) linear dunes occupy $7500 \mathrm{~km}^{2}$ in the southeastern Nebraska Sand Hills. These dune crests are oriented roughly $\mathrm{N} 65^{\circ} \mathrm{W}$ and have been interpreted morphodynamically as longitudinal dunes indicative of bidirectional winds of subequal strength. They suggest northerly winds between about 340 and $20^{\circ}$ and southwesterly winds between 212 and $250^{\circ}$ (Figure 2; Sridhar et al., 2006). The orientation of these dunes is similar to that of the larger, older dunes that lie just to the west, strongly suggesting that, in the eastern Sand Hills, the wind regime during dune-building episodes remained unchanged from Late Pleistocene to Late Holocene. We measured 85 cross-bed orientations within trenches cut 


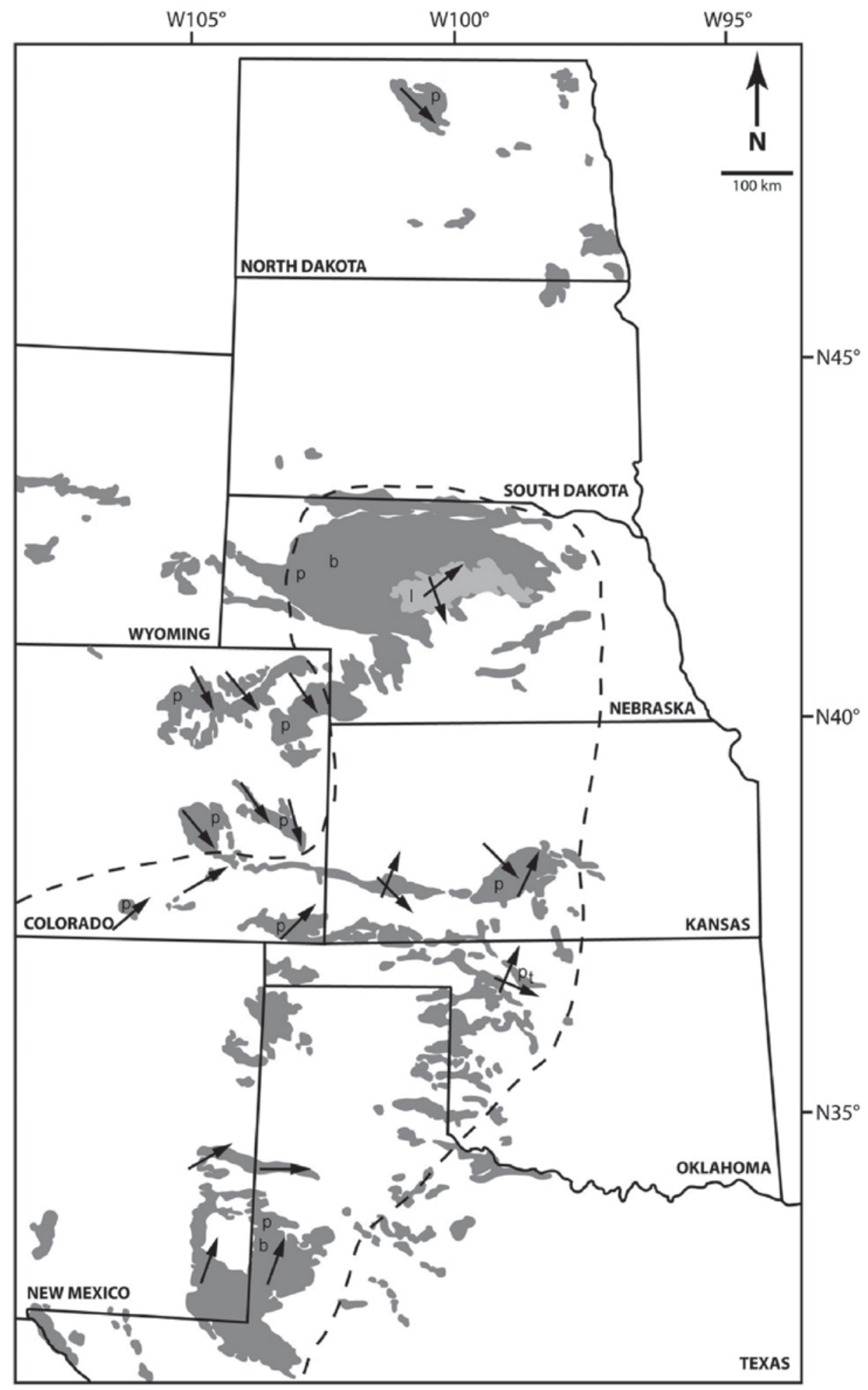

Figure 2. Map of Great Plains dune fields (gray shading, after Muhs and Holliday (1995)-central and southern Great Plains and Muhs and Wolfe (1999)-northern Great Plains) with late Holocene paleowind directions (black arrows). Light gray shading designates location of linear dunes in the Nebraska Sand Hills. Ancient dune type are given in letters where $b=$ barchanoid-ridge, $1=$ linear, $p=$ parabolic, and $t=$ transverse.

through eight longitudinal dunes throughout the southeastern Sand Hills. These measurements are consistent with bidirectional paleowinds coming from the north and southwest that caused sand to accrete along both sides of the bed forms during the late Holocene (Figure 3).

Several late Holocene dune fields are present in the eastern portion of Colorado (Figure 1; Table 2). In the northeast- ern part of the state, the South Platte dune field is divided into the Greeley dune field, on the north side of the South Platte River and the Fort Morgan dune field, on the south side of the South Platte River (Muhs, 1985; Madole, 1995; Muhs et al., 1996). Dune sand in the South Platte dune field averages 10$25 \mathrm{~m}$ in thickness with a maximum thickness of $30 \mathrm{~m}$ (Madole, 1994, 1995; Muhs et al., 1996). The Wray dune field is located 
Table 2. Information about late Holocene Great Plains dune fields in North America.

\begin{tabular}{|c|c|c|c|c|c|c|}
\hline Dune field & References & $\begin{array}{r}\text { Size } \\
\left(\mathrm{km}^{2}\right)\end{array}$ & $\begin{array}{l}\text { Paleowind } \\
\text { direction }\end{array}$ & $\begin{array}{l}\text { Ancient } M \\
\text { dune type }\end{array}$ & $\begin{array}{l}\text { Modern } \\
\text { RDD }\end{array}$ & $\begin{array}{l}\text { Hypothetical } \\
\text { dune type }\end{array}$ \\
\hline Minot dune field & $\begin{array}{l}\text { Muhs et al., 1997a; } \\
\text { Muhs et al., 1997b; } \\
\text { Muhs and Wolfe, } 1999\end{array}$ & 1500 & $\mathrm{~N} 45^{\circ} \mathrm{W}$ & Parabolic & $117^{\circ}$ & Transverse or parabolic \\
\hline Nebraska Sand Hills & $\begin{array}{l}\text { Swinehart, 1998; } \\
\text { Sridhar et al., } 2006\end{array}$ & 57,000 & N major; SW sub. & Various & $128^{\circ}$ & Oblique \\
\hline South Platte dune field & Madole, 1995; Muhs et al., 1996 & 7500 & $\mathrm{~N} 27^{\circ} \mathrm{W}$ & Parabolic & $149^{\circ}$ & Transverse or paraboli \\
\hline Big Sandy eolian sand area & Madole, 1995 & 2430 & NW & Parabolic & $152^{\circ}$ & Oblique to transverse \\
\hline Apishapa sand area & Madole, 1995 & 340 & SW & Parabolic & $113^{\circ}$ & Longitudinal to transverse \\
\hline Baca eolian sand area & Madole, 1995 & 2500 & SW & Parabolic & $113^{\circ}$ & Longitudinal to transverse \\
\hline Great Bend Sand Prairie & Arbogast, 1995, 1996, 1998 & 4500 & SW major; NW sub. & Parabolic & $20^{\circ}$ & Oblique \\
\hline Arkansas River dune field & $\begin{array}{l}\text { Olson et al., 1997; } \\
\text { Forman et al., } 2008\end{array}$ & & N-NW & $\begin{array}{c}\text { Transverse, } \\
\text { parabolic }\end{array}$ & $66^{\circ}$ & Oblique \\
\hline
\end{tabular}

southeast of the South Platte dune field and directly north of the Arikaree River and stretches east into Nebraska. The dune field has an average sand thickness of $30 \mathrm{~m}$ and maximum thickness of $50 \mathrm{~m}$ (Madole, 1995). The dune fields of northeastern Colorado (South Platte and Wray) were last active during the late Holocene, when conditions were windier and warmer than at present (Forman et al., 1995). A sample from the dunes dated using radiocarbon dating suggests a maximum limiting age of $\sim 1500$ yr B.P. (Muhs et al., 1996), but many additional dates suggest that the dunes were most likely active at or slightly after 1000 yr B.P. (Madole, 1995; Forman et al., 1995; Muhs et al., 1996). Some authors have noted evidence for dune activity in this area around 600 years ago (Forman et al., 1995; Clarke and Rendell, 2003), but these events seem to be localized, having little impact on large-scale dune migration.

Simple and compound parabolic dunes are the most common dune type in the South Platte and Wray dune fields (Figure 2). Some sand sheets are also present (Muhs, 1985; Madole, 1994, 1995; Forman et al., 1995; Muhs et al., 1996). Additionally, dunes that appear to be longitudinal dunes may be parabolic dunes with the concentric edges deflated (Forman et al., 1995;

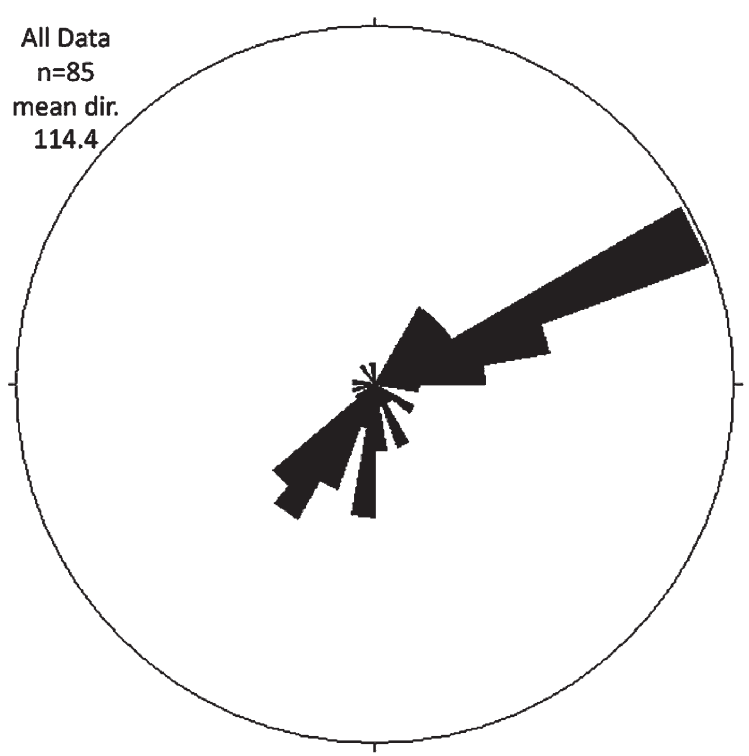

Figure 3. Rose diagram illustrating cross-bed orientations measured in sections cut through linear dunes in the Nebraska Sand Hills.
Madole, 1995). The arms of the parabolic dunes are oriented to northwest with the concentric edge (nose) downwind, to the southeast (Muhs, 1985; Forman and Maat, 1990; Forman et al., 1995; Madole, 1995) and dune crests oriented southwest-northeast. In the Greeley dune field, the arms are oriented $\mathrm{N} 27^{\circ} \mathrm{W}$ and in the Wray dune field the arms are oriented $\mathrm{N} 35^{\circ} \mathrm{W}$ (Muhs et al., 1996) with the dune crests oriented southwest-northeast in both. All of the data suggest northwesterly late Holocene paleowinds for northeastern Colorado (Figure 2).

Five other dune fields located in east-central and southeastern Colorado include the Black Squirrel, Big Sandy, Arkansas River, Apishapa, and Baca eolian sand areas (Figure 1; Table 2). The Black Squirrel eolian sand area in east-central Colorado contains dunes up to $42 \mathrm{~m}$ thick. The Big Sandy eolian sand area is located along the Big Sandy Creek in east-central Colorado and has dunes up to $20 \mathrm{~m}$ thick (Madole, 1995). In the Arkansas River eolian sand area, located from La Junta to the border with western Kansas, dunes are up to $25 \mathrm{~m}$ thick. The Apishapa sand area consists of six small areas of dunes in southeastern Colorado. Finally, the Baca eolian sand area is located in the southeastern corner of Colorado and consists of dunes approximately $15 \mathrm{~m}$ thick (Madole, 1995).

The dune fields in east-central and southeastern Colorado are hypothesized to have been active less than 1000 years ago (Madole, 1995). High compound parabolic dunes are most common with some blowout dunes present in the Arkansas River eolian sand area. The dunes in the Black Squirrel and Big Sandy eolian sand areas suggest paleowind directions from the northwest with some component of southwesterly winds recognized in the southern part of the Black Squirrel dune field (Figure 2). Within the Apishapa and Baca eolian sand areas, dunes are oriented suggesting southwesterly paleowinds (Figure 2). Dunes in the Arkansas River eolian sand area are not well studied (Madole, 1995).

The Great Bend Sand Prairie is located in the bend of the Arkansas River in central Kansas (Figure 1, Table 2). Dunes in this sand prairie are about $15 \mathrm{~m}$ thick and were last active during the late Holocene, within the last 1000 years (Arbogast, 1995, 1996, 1998). Simple and compound parabolic dunes are the most common dune type in the Great Bend Sand Prairie. Some sand sheets with low relief and sand sheets with high relief are also present in the dune field. A large lunette dune known as Wilson Ridge is located in the west-central part of the dune field and formed during the late Wisconsin, approximately 20,000 years ago (Arbogast, 1995). 
The crests of most of the parabolic dunes in the Great Bend Sand Prairie are oriented northwest-southeast with concentric edges downwind, to the northeast, suggesting southwesterly paleowind directions for the last period of reactivation. Some of the orientations of the parabolic dunes suggest northwesterly paleowind directions (Arbogast, 1995, 1996, 1998; Arbogast and Muhs, 2000). Arbogast (1995) suggested the two wind directions could be seasonal with northwesterly winds likely occurring during the winter and the stronger southwesterly winds occurring during the summer. However, as parabolic dunes form under unimodal wind regimes, it is more likely that these wind directions influenced dune activity at different times.

The High Plains of Kansas directly south of the Arkansas River and directly south of the Cimarron River also contains several small dune fields, known collectively as the Arkansas River dune field (Figure 1; Table 2). Dune sand ranges from 1 to $18 \mathrm{~m}$ thick with transverse and parabolic dunes present. The oldest dates from the Arkansas River dune field range from 16 to $12 \mathrm{ka}$, while there is evidence for small, more recent events at 430, 380320,180 , and 70 yrs ago. No evidence of dune reactivation during the Medieval Climatic Anomaly has been found, likely due to an incomplete record (Forman et al., 2008). Paleowinds are recognized as northerly to northwesterly (Forman et al., 2008) as indicated by loess distribution as well as the weak trend of dunes in the area (south-southwest to north-northeast). Some inconsistencies in loess thickness and particle size from the source region suggest variable south to southwesterly winds (Olson et al., 1997) that may also have reworked the dunes to some degree.

Small dune fields are present along the northern edge of the Cimarron River in north-central Oklahoma, (Figure 1; Table 2; Brady, 1989). The dunes were last active in the late Holocene, about 770-880 years ago (Lepper and Scott, 2005). Transverse ridges with some barchanoid characteristics are common in the dune fields. To the northeast, parabolic dunes are more common, likely due to a lower sand supply in this area (Brady, 1989). Most of the dunes indicate south-southwesterly paleowinds based on orientations of slipfaces although some suggest west-northwesterly to northwesterly winds which may indicate bimodal paleowinds for the area (Figure 2; Brady, 1989).

The Southern High Plains of Texas is a large plateau located in the western part of the panhandle of Texas, spreading into easternmost New Mexico. Scattered dune fields are present across the Southern High Plains (Figure 1; Table 2) and are commonly located near playas (Reeves, 1965; Holliday, 1991). There are three main dune fields, the Muleshoe dunes, the Lea-Yoakum dunes, and the Monahans-Andrews dunes. The Muleshoe dunes are a west-east trending dune field located in and downwind of Portales Valley. The Lea-Yoakum dune field also trends west-east and is located downwind of the Simanola Valley. The Monahans-Andrews dunes follow the Pecos River Valley and are partially active (Holliday, 2001). The Muleshoe and Lea-Yoakum dunes were last active during the late Holocene, with the greatest drought occurring from 1500 to 1400 yr B.P. (Holliday, 1991, 2001).

The majority of the dune types present on the Southern High Plains formed under unimodal wind regimes. These dunes include parabolic dunes, coppice dunes, barchan dunes, barchanoid dunes, and sand sheets. The suggestion of a unimodal wind regime may be misleading as some of the dune fields are located directly downwind of major valleys roughly parallel to prevailing winds, possibly leading to funneling of the winds and an erroneous assessment of dune-building winds. In some areas, complex dunes are present suggesting bimodal wind regimes (Holliday, 2001). Orientations of the dunes imply southwesterly paleowinds (Figure 2; Reeves, 1965; Holliday, 1991), with parabolic dunes having an average arm orientation of $\mathrm{N} 20^{\circ} \mathrm{E}$ (Reeves, 1965), and dune crest orien- tations of $\mathrm{N} 70^{\circ} \mathrm{W}$. Dunes in the Muleshoe dune field indicate westerly paleowinds with parabolic arm orientations ranging from $\mathrm{N}^{\circ} 9^{\circ} \mathrm{E}$ to $\mathrm{S} 86^{\circ} \mathrm{E}$ (Muhs and Holliday, 2001).

All of the information from ancient dune fields provides information about late Holocene circulation patterns across the portion of the Great Plains within the U.S.A. (Figure 2). The wind regime was unimodal on the northern end of the Great Plains, with northwesterly paleowinds. To the south, the wind regime was also unimodal, but paleowinds were south-southwesterly. Intermediate areas were under a bimodal wind regime and were influenced by both northwesterly and southsouthwesterly paleowinds.

\section{Modern wind directions}

Strong winds across the Great Plains are predominantly dry and cold northwesterly winds associated with the cold front in mid-latitude cyclones. These winds dominate the mean surface winds and drift potential over the region during the winter months (Figure 5). During spring and early summer, anticyclonic flow around the Bermuda High (the North Atlantic subtropical high) creates northward flow of moist air from the Gulf of Mexico, which is often referred to as the Great Plains low-level jet and conveys much of the moisture that ultimately falls as precipitation on the Great Plains (Sun and Muhs, 2007; Wang et al., 2007; Feng et al., 2008). These southerly to southeasterly winds also strongly influence summer drift potential over large areas of the Great Plains (Figure 6). The strongest winds over the area occur during the spring months as evidenced by drift potential calculations. These winds could be particularly influential on dune activation because soil and sediment are particularly dry during this season.

\subsection{North Dakota}

Modern drift potential vectors over the Minot dune field (Minot, ND) are mainly unidirectional and are out of the northwest (Figure 4). A resultant drift direction (RDD) of $117^{\circ}$ (indicating net hypothetical sand transport from $\mathrm{N} 63^{\circ} \mathrm{W}$ ) was calculated (Table 1 and Table 2). Strong northwesterly winds (Figure 5), most common in winter, are typically dry and cold (Muhs and Wolfe, 1999). Seasonally, a minor component of southeasterly winds (Figure 6) from the Gulf of Mexico brings warm, moist air for the months of June, July, and August. Hypothetical dune crests forming under the present wind regime would trend southwest-northeast $\left(33^{\circ}\right)$. The difference between the hypothetical dune trend and resultant sand transport $\left(84^{\circ}\right)$ indicates that transverse or parabolic dunes would form under modern wind conditions. Parabolic late Holocene dunes within the Minot dune field also indicate winds from the northwest, indicating little change in prevailing winds from the late Holocene to the present over the Minot dune field.

\subsection{Nebraska}

Strong northwesterly winds, most frequent in winter, dominate potential sand transport in the Nebraska Sand Hills at present (Figure 4 and Figure 5; Ainsworth, Alliance, Brewster, Broken Bow, Cozad, Mullen, North Platte, O'Neill, Ord, and Valentine, NE). A weaker south-southeasterly component is present mainly in summer (Figure 4 and Figure 6). An average RDD for all of the stations around or near the Nebraska Sand Hills was calculated at $128^{\circ}$ (net hypothetical sand transport from $\left.\mathrm{N} 52^{\circ} \mathrm{W}\right)$. A hypothetical dune forming under the present winds would be oriented southwest-northeast $\left(65^{\circ}\right)$ and would be classified morphodynamically as oblique (Table 2). In contrast, elongate late Holocene dunes in the Nebraska Sand Hills are longitudinal and are oriented northwest-southeast (Sridhar et al., 2006), indicating a major change in wind 


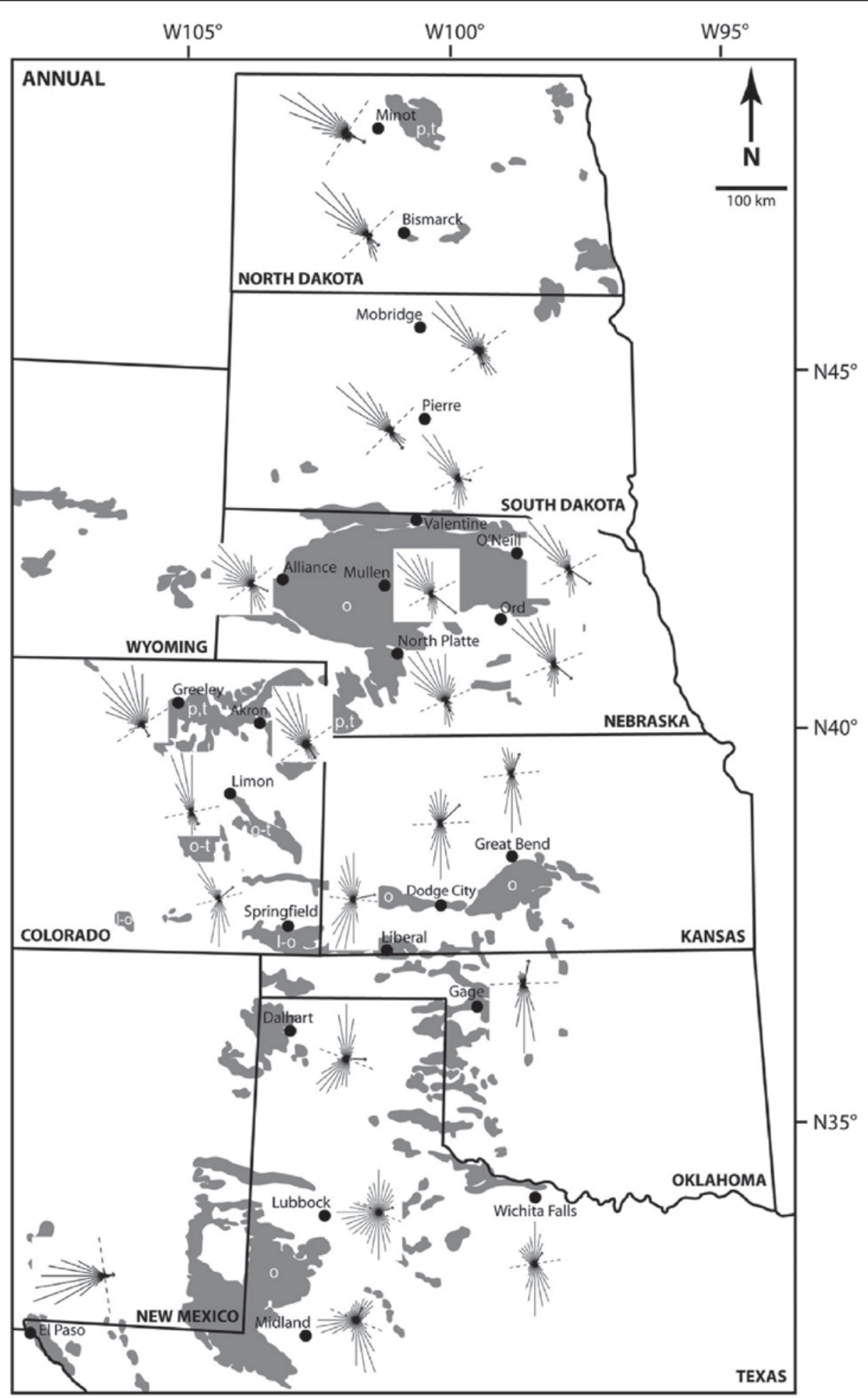

Figure 4. Map of Great Plains dune fields (gray shading, after Muhs and Holliday (1995)-central and southern Great Plains and Muhs and Wolfe (1999)-northern Great Plains) with modern sand roses for stations across the region. Dashed lines indicate hypothetical modern dune orientation and arrows indicate hypothetical modern RDD. Hypothetical dune types under modern winds are given in letters where $1=$ longitudinal, $\mathrm{o}=$ oblique, $\mathrm{p}=$ parabolic, and $\mathrm{t}=$ transverse.

direction. While the northwesterly component of drift potential remained constant from the last reactivation to the present, the southerly component varied from southwesterly during the late Holocene to south-southeasterly at present.

\subsection{Colorado}

Over northeastern Colorado (Akron and Greeley, CO) potential sand transport is dominated by strong winds out of the northwest that persist over the region during the fall, winter, and spring, with subordinate winds out of the southeast mainly during the summer (Figures 4-6). Southeasterly summer winds are stronger between the South Platte and Wray dune fields (Akron, CO) than to the west of the South Platte River (Greeley, CO), where southeasterly winds are very minor. The average RDD as calculated for stations near the South Platte and Wray dune fields is $149^{\circ}$ (net hypothetical sand 


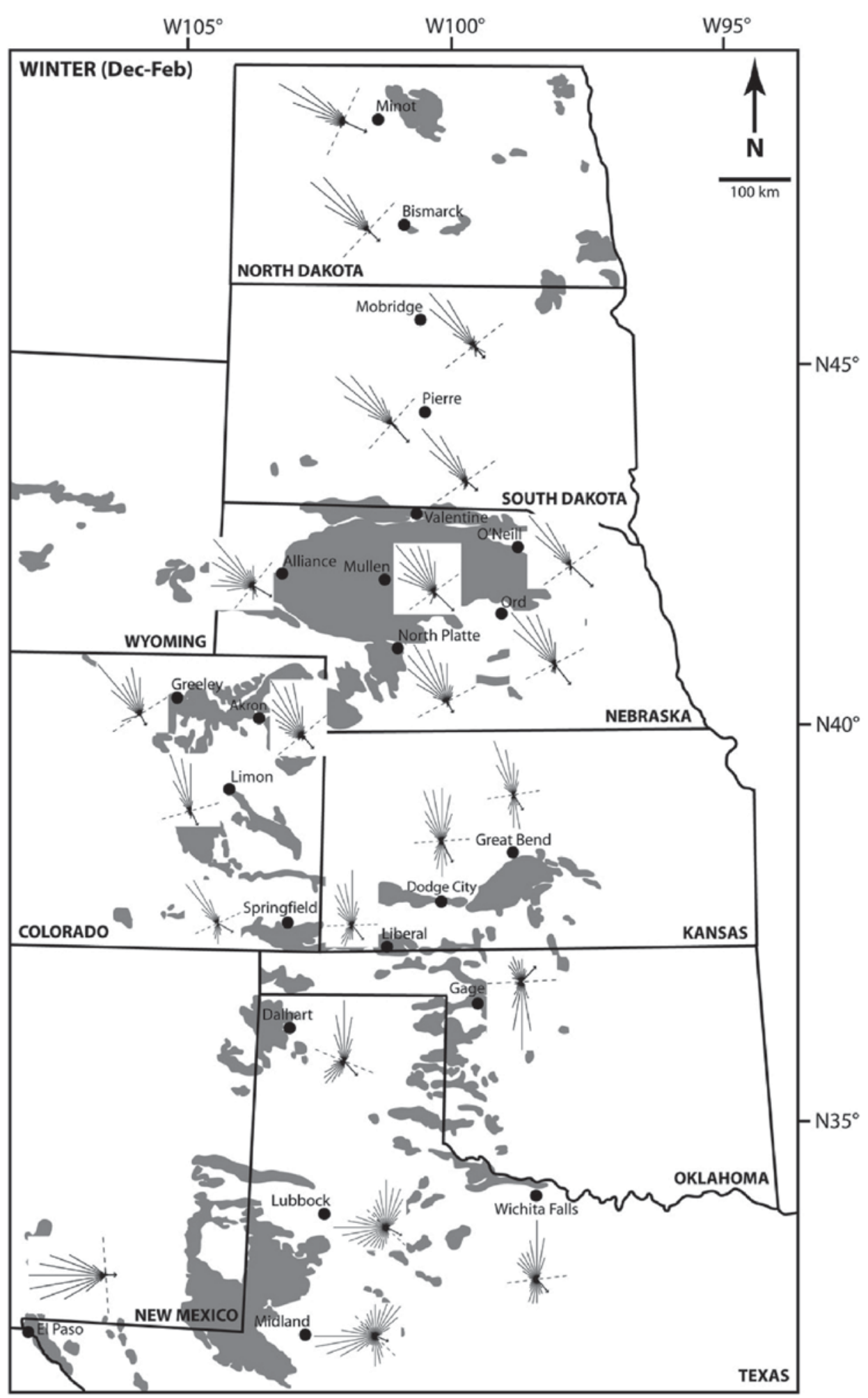

Figure 5. Map of Great Plains dune fields (gray shading, after Muhs and Holliday (1995)-central and southern Great Plains and Muhs and Wolfe (1999)-northern Great Plains) with modern sand roses for winter (the months of December through February). Dashed lines indicate hypothetical modern dune orientation and arrows indicate hypothetical modern RDD.

transport from $\left.\mathrm{N} 31^{\circ} \mathrm{W}\right)$. Hypothetical dune crests forming under present winds would be oriented southwest-northeast $\left(56^{\circ}\right)$. According to the morphodynamic classification, transverse or parabolic dunes would form under these conditions (Table 2). Hypothetical modern dune type and orientation match those of the late Holocene dunes, with no evidence of a stronger southerly wind component than at present, indicating little change in wind patterns since the dunes formed.
Winds out of the northwest dominate drift potential over east-central Colorado (Limon, CO), with a small component added by southerly winds, mainly in summer (Figures 4-6) and a calculated RDD of $152^{\circ}$ (net hypothetical sand transport from $\mathrm{N} 28^{\circ} \mathrm{W}$ ). A hypothetical dune forming under modern conditions would be oblique to transverse (Table 2) and oriented nearly west-east $\left(78^{\circ}\right)$ while late Holocene dunes in the region are parabolic and oriented southwest-northeast, sug- 


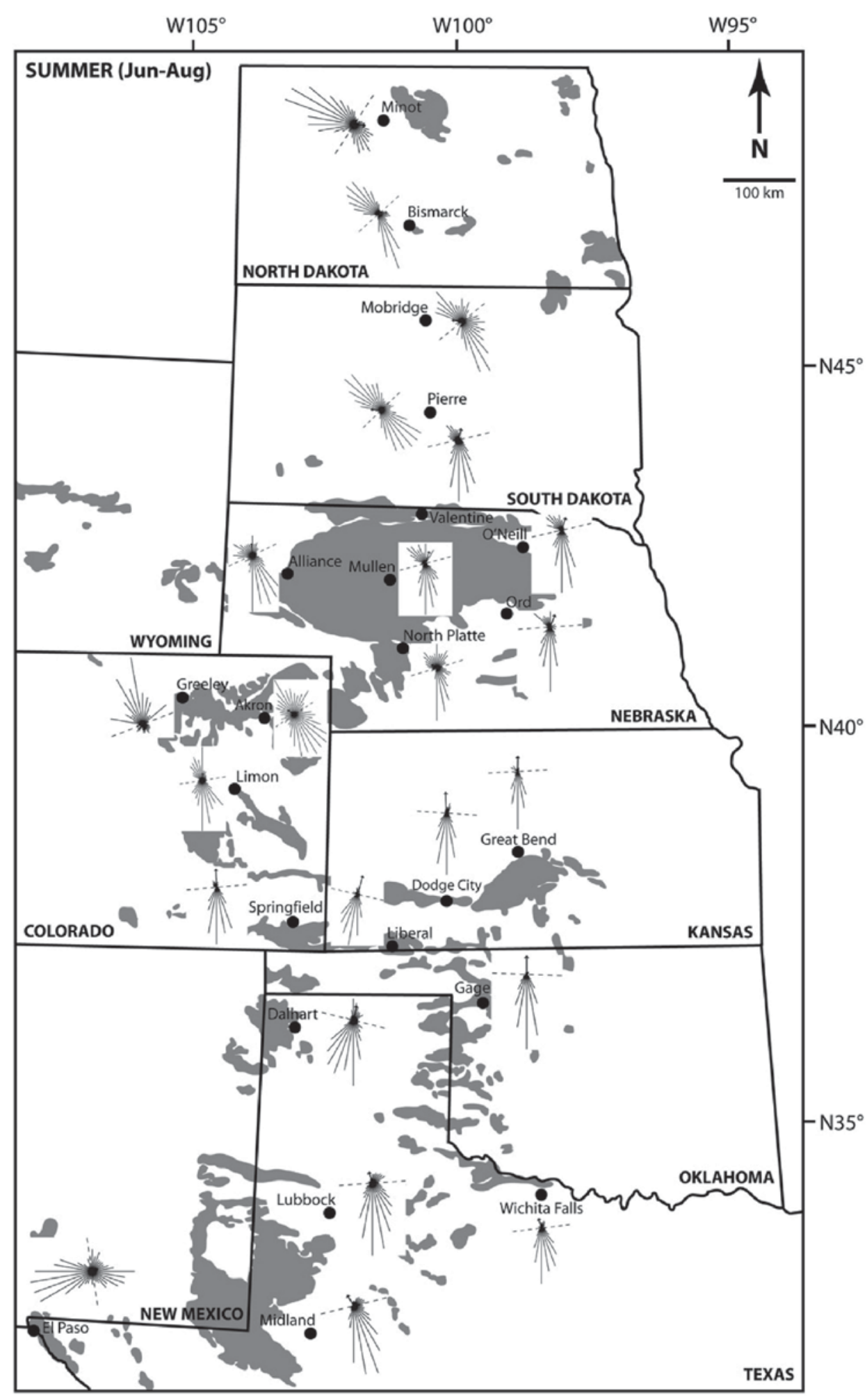

Figure 6. Map of Great Plains dune fields (gray shading, after Muhs and Holliday (1995)-central and southern Great Plains and Muhs and Wolfe (1999)-northern Great Plains) with modern sand roses for summer (the months of June through August). Dashed lines indicate hypothetical modern dune orientation and arrows indicate hypothetical modern RDD.

gesting a major change in wind direction. In southeastern Colorado (La Junta, Lamar, and Springfield, CO), drift potential due to southerly winds during the spring, summer, and fall is equal to or greater than potential sand transport by northwesterly winds (Figure 4). The calculated average RDD for southeastern Colorado is $113^{\circ}$ with a hypothetical dune crest orientation of $98^{\circ}$ (roughly west-east). A hypothetical dune forming in southeastern Colorado would be classified morphodynamically as longitudinal to oblique. Present winds are equivalent to paleowinds in the east-central portion of the state with northwesterly winds dominating. However, the dune fields in southeastern Colorado show paleowinds from the southwest (Madole, 1995), while modern winds originate mainly from the south with a component of northwesterly winds. 


\subsection{Kansas}

Winds that dominate potential sand transport in south-central Kansas (Great Bend, KS; Figure 4) are presently out of the south, especially in the summer (Figure 6) with a weaker component of northwesterly winds that occur mainly in winter (Figure 5). An RDD of $20^{\circ}$ (net hypothetical sand transport from $520^{\circ} \mathrm{W}$ ) was calculated (Table 2). The modern RDD matches the paleowind direction reflected in the Great Bend Sand Prairie. However, dominant paleowinds were southwesterly while at present, strong winds are predominately southerly. Additionally, hypothetical dunes forming under modern winds would be oblique dunes oriented nearly west-east $\left(84^{\circ}\right)$ while the late Holocene dunes are parabolic dunes oriented northwest-southeast. Over southwestern Kansas (Dodge City, Elkhart, Garden City, and Liberal, KS), northerly and southerly winds have roughly equal influence on potential sand transport, or the northerly component is slightly weaker. The average RDD for this area is $66^{\circ}$ (net hypothetical sand transport from $\mathrm{S} 66^{\circ} \mathrm{W}$ ). Hypothetical dunes forming under modern winds would be oblique dunes with crests oriented roughly west-east $\left(87^{\circ}\right)$ while late Holocene dunes are oriented south-southwest to north-northeast.

\subsection{Oklahoma}

Modern drift potential near the Cimarron River dune fields (Gage, OK) is mainly generated by winds out of the south, with some influence of very weak northwesterly winds in winter (Figures $4 \& 5$ ). An RDD of $11^{\circ}$ was calculated near the Cimarron River dune fields. Modern winds would form transverse or parabolic hypothetical dunes with west-east $\left(88^{\circ}\right)$ orientations (Table 2$)$. The late Holocene dunes are also parabolic, but are oriented northwest-southeast. The winds that shaped the dunes at the time they were last active were shifted to the southwest, as compared to the southerly winds that would dominate sand transport today. The dunes provide no evidence for a stronger northwesterly component of winds during the last reactivation than at present.

\subsection{Texas}

Presently, northerly winds generate the greatest drift potential in the winter (Figure 5) and southerly to southwesterly winds are most important during the summer (Figure 6) across the Southern High Plains (Lubbock and Midland, TX; Figure 4). A calculated average RDD of $49^{\circ}$ (net hypothetical sand transport from $S 49^{\circ} \mathrm{W}$ ) shows that resultant winds are southwesterly at present unlike the westerly paleowinds. Hypothetical dunes forming under present winds would have crests oriented west-northwest to east-southeast $\left(\mathrm{S} 66^{\circ} \mathrm{E}\right)$ and would be classified morphodynamically as oblique dunes (Table 2). Simple late Holocene dunes in the region are oriented more strongly southwest-northeast $\left(\mathrm{N} 20^{\circ} \mathrm{E}\right)$. The influence of southwesterly winds is consistent between late Holocene episodes of dune activity and the present, but the strong northerly winds that currently blow over the region today have replaced more westerly winds that shaped late Holocene dunes.

\subsection{Summary of changes in wind patterns}

In the northern parts of the Great Plains, few changes are seen in wind regimes between the present and late Holocene episodes of dune mobility (compare Figure 2 and Figure 4). North Dakota and northern Colorado dune fields indicate unidirectional wind regimes with the same strong northwesterly winds during the late Holocene dune activity and at present. Further south, within Nebraska, differences in wind regimes are apparent. While both paleowinds reconstructed from late Holocene dunes and present wind regimes are bidirectional with a component of northwesterly winds, predominant summer winds at present are south to southeasterly while summer winds that shaped late Holocene dunes were southwesterly. Dune fields in southeastern Colorado also record this shift in winds, indicating a unidirectional wind regime with strong southwesterly winds during late Holocene dune activity. The modern sand roses for southeastern Colorado reflect mainly northwesterly and southerly winds. To the east in central Kansas, a similar change in wind regime is recorded. Late Holocene dunes indicate a bidirectional wind regime with southwesterly and northwesterly components. The present wind regime is also bidirectional, but with southeasterly and north to northwesterly components. In Oklahoma and Texas, the furthest southern extent of the Great Plains, late Holocene dunes indicate a unidirectional wind regime with predominance of southwesterly winds. The present wind regime is bidirectional with northerly and south-southwesterly components.

\section{Possible cause for late Holocene megadroughts}

During winter months, the Great Plains are relatively dry, but during summer, moist air flow from the Gulf of Mexico (the Great Plains low-level jet) is generated by anticyclonic circulation around the Bermuda High, resulting in increased precipitation (Wang et al., 2007; Feng et al., 2008). For drought to persist over the region, this moisture transport must be reduced, which can occur when the Bermuda High weakens and/or its center shifts to the east or south (Forman et al., 2001; Wang et al., 2007). Modeling studies indicate that broader controls on Great Plains drought may include both unusually warm sea-surface temperature (SST) in the subtropical North Atlantic and anomalously cool SST in the eastern tropical Pacific, both of which result in reduced moisture transport into the Great Plains (Feng et al., 2008). A weakened Great Plains low-level jet, resulting from a weakened and/or shifted Bermuda High could allow more frequent southwesterly winds in the Great Plains. Presently, dry and hot southwesterly winds flow from Mexico and the southwestern U.S. towards the Great Plains during the spring and summer months, generally rising over the moist southerly to southeasterly flow from the Gulf in the southern Great Plains. If the moist air flow from the Gulf was weakened, hot and dry southwesterly surface winds could often extend much farther north and northeast over the Great Plains (Sridhar et al., 2006). In eastern New Mexico, west Texas, and western Oklahoma, however, southwesterly flow needn't always be dry. Summer flow into this area from the Gulf of California can bring considerable moisture, but has relatively little effect further east and north. The southwesterly flow of air could also have been brought to the surface through a feedback mechanism involving land surface changes resulting from drought (Sridhar et al., 2006). Either or both of these mechanisms can explain the southwesterly paleowinds that are recognized from the late Holocene dunes throughout the lower parts of the Great Plains.

It is also extremely important to consider feedback mechanisms that may contribute to persistence of dry conditions over the Great Plains, allowing full dune reactivation to take place. Evapotranspiration from plants is an additional source of atmospheric moisture that can be recycled as precipitation. The reduction in vegetative density by drought decreases that source of moisture, leading to further diminishing of the vegetative cover. A soil moisture feedback mechanism works in a similar manner (Oglesby and Erickson, 1989; Sridhar et al., 2006).

\section{Conclusions}

Paleowind information from late Holocene dunes across the Great Plains of North America provides a detailed picture of past circulation patterns (Figure 2). A comparison between 
past and present wind regimes over the region shows one major difference, strong southwesterly winds were more frequent than at present across much of the central and southern Great Plains during late Holocene episodes of dune activity (compare Figure 2 and Figure 4), changing the predominant direction(s) of potential sand transport. Unimodal northwesterly winds dominate potential sand transport in the northern part of the Great Plains (North Dakota) at present, and were also dominant when late Holocene dunes were active. If dunes were to form under present conditions in the northern Great Plains, they would be very similar in morphology (transverse or parabolic) and orientation to those that formed during the late Holocene. In the central Great Plains (Nebraska) late Holocene and present wind regimes were bimodal, with one important difference. While potential sand transport by northwesterly winds was high during both time periods, secondary modern winds are southerly to southeasterly while secondary late Holocene winds were southwesterly. Consequently, dunes forming under present winds would have remarkably different crestal orientations (SW-NE) than those from the late Holocene (NW-SE). The pattern of stronger southwesterly winds during late Holocene dune activity is also evident farther south. While bimodal winds from the south and northwest currently dominate southern Colorado and Kansas, and would lead to oblique or transverse dune formation, parabolic dunes formed by southwesterly winds are recognized from the late Holocene. Furthest to the south (in Texas), modern prevailing winds are quite variable, ranging from south-southwesterly to westerly to northerly. Dunes forming over the region would also be quite variable and include oblique dunes. Late Holocene parabolic dunes were formed by unimodal southwesterly winds.

Strong northwesterly winds have provided a persistent component of drift potential across the northern and central Great Plains from at least the late Holocene to the present. The other major component of drift potential, resulting from winds out of the south has undergone a major shift over central to southern portions of the Great Plains, from southwesterly during late Holocene dune activity to southerly or southeasterly at present. It is likely that this shift in wind directions resulted from the weakened northward flow of moist air from the Gulf of Mexico that produced late Holocene megadroughts and allowed dune reactivation. Reduced air flow and moisture transport from the Gulf resulted in turn from a weakened or shifted Bermuda High and possible broader connections with the Atlantic and Pacific SST.

The likelihood of further reactivation of the dune fields is an obvious concern. Droughts recognized from the 19th and 20th centuries (the Dust Bowl being one example) have shown that the dunes are extremely sensitive to changes in climate. Minor reactivation of the dunes took place during several of the longer lasting droughts (Ahlbrandt et al., 1983; Muhs and Holliday, 1995). Several authors have reported dune fields in northeastern Colorado, western Nebraska, and central Kansas as currently being near the threshold for reactivation, with numerous small areas of bare sand (Madole, 1994; Muhs et al., 1996). Dunes in the northern part of the Great Plains, such as those within the Minot dune field, may be more vulnerable to reactivation due to their small size and the shorter growing season. These dune fields may actually be the first to reactivate in the event of another megadrought (Muhs and Wolfe, 1999). Future predictions of increased temperatures and decreased summer precipitation across the Great Plains (Christensen et al., 2007) suggest that global climate changes will almost certainly have a major impact on the Great Plains. Given the geologic record of sensitivity of the dune fields in this area to climate change, future dune reactivation could occur again, but the influence of invasive plant species and the advent of new land management techniques make this difficult to assess.

\section{Acknowledgments}

The authors thank the two reviewers (Dan Muhs and Steve Forman) for their comments, which greatly improved the quality of the paper. We also greatly appreciate the support of the Department of Geosciences at the University of Nebraska-Lincoln as well as the following committee members for assistance with this project: Dr. Tracy Frank, Dr. Ron Goble, Dr. Matt Joeckel, and Professor Jim Swinehart. Many thanks go to Dr. Xiadong Miao, who provided invaluable help in teaching the process of analyzing meteorological data. We also thank Andy Applegarth, for assistance in countless things while research was conducted at the Gudmundsen Sand Hills Laboratory, and to the national park service for help obtaining permits to conduct work at the Nebraska National Forest. Finally, many thanks go to Diane Schmeisser for support and field work assistance. Funding for this project was provided by National Science Foundation Grant DEB 0233067.

\section{References}

Ahlbrandt and Fryberger, $1980<$ T. S. Ahlbrandt and S. G. Fryberger, Eolian deposits in the Nebraska sand Hills, United States Geological Survey Professional Paper 1120A (1980), pp. 1-24.

Ahlbrandt et al., $1983<$ T. S. Ahlbrandt, J. B. Swinehart and D. G. Maroney, The dynamic Holocene dune fields of the Great Plains and Rocky Mountain basins, U. S. A. . In: M. E. Brookfield and T. S. Ahlbrandt, Editors, Eolian Sediments and Processes, Elsevier, Amsterdam (1983), pp. 379-406.

Arbogast, 1995 Arbogast, A. F., 1995. Paleoenvironments and desertification on the Great bend sand prairie in Kansas. Ph. D. thesis, Lawrence University of Kansas.

Arbogast, 1996 A. F. Arbogast, Stratigraphic evidence for late-Holocene Aeolian sand mobilization and soil formation in south-central Kansas, U. S. A, Journal of Arid Environments 34 (1996), pp. 403-414.

Arbogast, 1998 A. F. Arbogast, Late quaternary paleoenvironments and landscape evolution on the Great bend sand prairie, Kansas Geological Survey Bulletin 242 (1998), pp. 1-72.

Arbogast and Johnson, 1998 A. F. Arbogast and W. C. Johnson, Late-quaternary landscape response to environmental change in south-central Kansas, Annals of the Association of American Geographers 88 (1998), pp. 126-145.

Arbogast and Muhs, $2000 \backsim$ A. F. Arbogast and D. R. Muhs, Geochemical and mineralogical evidence from eolian sediments for northwesterly mid-Holocene paleowinds, central Kansas, U. S. A., Quaternary International 67 (2000), pp. 107-118.

Brady, 1989 R. G. Brady, 1989. Geology of the Quaternary Dune Sands in Eastern Major and Southern Alfalfa Counties, Oklahoma. Ph. D. thesis, Stillwater, Oklahoma State University.

Christensen et al., $2007 \varangle$ J. H. Christensen, B. Hewitson, A. Busuioc, A. Chen, X. Gao, I. Held, R. Jones, R. K. Kolli, W. -T. Kwon, R. Laprise, V. Magaña Rueda, L. Mearns, C. G. Menéndez, J. Räisänen, A. Rinke, A. Sarr and P. Whetton, Regional climate projections. In: S. Solomon, D. Qin, M. Manning, Z. Chen, M. Marquis, K. B. Averyt, M. Tignor and H. L. Miller, Editors, The Physical Science Basis. Contribution of Working Group I to the Fourth Assessment Report of the Intergovernmental Panel on Climate Change, Cambridge University, Cambridge, UK (2007), pp. 847-940.

Clarke and Rendell, $2003 \rightarrow$ M. L. Clarke and H. M. Rendell, Late Holocene dune accretion and episodes of persistent drought in the Great Plains of northeast Colorado, Quaternary Science Reviews 22 (2003), pp. 1051-1058.

Cook et al., 2004 E. R. Cook, C. A. Woodhouse, C. M. Eakin, D. M. Meko and D. W. Stahle, Long-term aridity changes in the western United States, Science 306 (2004), pp. 1015-1018.

Feng et al., $2008<$ S. Feng, R. J. Oglesby, C. B. Rowe, D. B. Loope and Q. Hu, Atlantic and Pacific SST influences on Medieval drought in North America simulated by the community atmospheric model, Journal of Geophysical Research 113 (2008), p. D11101.

Forman and Maat, $1990 \varangle$ S. L. Forman and P. Maat, Stratigraphic evidence for late quaternary dune activity near Hudson on the Piedmont of northern Colorado, Geology 18 (1990), pp. 745-748.

Forman et al., 19954 S. L. Forman, R. Oglesby, V. Markgraf and T. Stafford, Paleoclimatic significance of Late Quaternary eolian deposition on the Piedmont and High Plains, central United States, Global and Planetary Change 11 (1995), pp. 35-55. 
Forman et al., $2001 \varangle$ S. L. Forman, R. Oglesby and R. S. Webb, Temporal and spatial patterns of Holocene dune activity on the Great Plains of North America: megadroughts and climate links, Global and Planetary Change 29 (2001), pp. 1-29.

Forman et al., 20054 S. L. Forman, L. Marín, J. Pierson, J. Gómez, G. H. Miller and R. S. Webb, Aeolian sand depositional records from western Nebraska: landscape response to droughts in the past 1500 years, The Holocene 15 (2005), pp. 973-981.

Forman et al., $2008<$ S. L. Forman, L. Marín, J. Gomez and J. Pierson, Late Quaternary eolian sand depositional record for southwestern Kansas: landscape sensitivity to droughts, Palaeogeography, Palaeoclimatology, Palaeoecology 265 (2008), pp. 107-120.

Fryberger, 1979 S. G. Fryberger, Dune forms and wind regime United States Geological Survey Professional Paper 1052. In: E. D. McKee, Editor, A Study of Global Sand Seas (1979), pp. 137-169.

Goble et al., $2004 \backslash$ R. J. Goble, J. A. Mason, D. B. Loope and J. B. Swinehart, Optical and radiocarbon ages of stacked paleosols and dune sands in the Nebraska Sand Hills, USA, Quaternary Science Reviews 23 (2004), pp. 1173-1182.

Holliday, $1991 \varangle$ V. T. Holliday, The geologic record of wind erosion, eolian deposition, and aridity on the Southern High Plains, Great Plains Research 1 (1991), pp. 6-25.

Holliday, 20014 V. T. Holliday, Stratigraphy and geochronology of upper quaternary eolian sand on the Southern High Plains of Texas and New Mexico, United States, GSA Bulletin 113 (2001), pp. 88-108.

Hunter et al., $1983 \varangle$ R. E. Hunter, B. M. Richmond and T. R. Alpha, Storm-controlled oblique dunes of the Oregon coast, Geological Society of America Bulletin 94 (1983), pp. 1450-1465.

Kocurek, 1996 G. A. Kocurek, Desert Aeolian systems. In: H. G. Reading, Editor, Sedimentary Environments: Processes, Facies, and Stratigraphy, Blackwell Science Ltd (1996), pp. 125-153.

Kutzbach and Wright, 19854 J. E. Kutzbach and H. E. Wright Jr., Simulation of the climate of 18,000 years BP: results for the North American/North Atlantic/European sector and comparison with the geologic record of North America, Quaternary Science Reviews 4 (1985), pp. 147-187.

Lancaster et al., 20024 N. Lancaster, G. Kocurek, A. Singhvi, V. Pandey, M. Deynoux, J. F. Ghienne and K. Lô, Late Pleistocene and Holocene dune activity and wind regimes in the western Sahara Desert of Mauritania, Geology 30 (2002), pp. 991-994.

Lepper and Scott, 20054 K. Lepper and G. F. Scott, Late Holocene Aeolian activity in the Cimarron River valley of west-central Oklahoma, Geomorphology 70 (2005), pp. 42-52.

Loope and Swinehart, $2000<$ D. B. Loope and J. B. Swinehart, Thinking like a dune field: geologic history in the Nebraska sand Hills, Great Plains Research 10 (2000), pp. 5-35.

Madole, $1994 \varangle$ R. F. Madole, Stratigraphic evidence of desertification in the west-central Great Plains within the past $1000 \mathrm{yr}$, Geology 22 (1994), pp. 483-486.

Madole, $1995 \varangle$ R. F. Madole, Spatial and temporal patterns of Late Quaternary eolian deposition, eastern Colorado, U. S. A., Quaternary Science Reviews 14 (1995), pp. 155-177.

Mason et al., $2004<$ J. A. Mason, J. B. Swinehart, R. J. Goble and D. B. Loope, Late-Holocene dune activity linked to hydrological drought, Nebraska Sand Hills, USA, The Holocene 14 (2004), pp. 209-217.

McKee, 19794 E. D. McKee, Introduction to a study of global sand seas Geological Survey Professional Paper 1052. In: E. D. McKee, Editor, A Study of Global Sand Seas (1979), pp. 1-19.

Miao et al., $2007<$ X. Miao, J. A. Mason, J. B. Swinehart, D. B. Loope, P. R. Hanson, R. J. Goble and X. Liu, A 10,000 year record of dune activity, dust storms, and severe drought in the central Great Plains, Geology 35 (2007), pp. 119-122.

Muhs, 19854 D. R. Muhs, Age and paleoclimatic significance of Holocene sand dunes in northeastern Colorado, Annals of the Association of American Geographers 75 (1985), pp. 566-582.

Muhs and Holliday, 19954 D. R. Muhs and V. T. Holliday, Evidence of active dune sand on the Great Plains in the 19th century from accounts of early explorers, Quaternary Research 43 (1995), pp. 198-208.
Muhs and Holliday, 2001 D. R. Muhs and V. T. Holliday, Origin of late quaternary dune fields on the southern high plains of Texas and New Mexico, GSA Bulletin 113 (2001), pp. 75-87.

Muhs and Wolfe, $1999<$ D. R. Muhs and S. A. Wolfe, Sand dunes of the northern Great Plains of Canada and the United States, Geological Survey of Canada Bulletin 534 (1999), pp. 183-197.

Muhs and Zárate, $2001<$ D. R. Muhs and M. Zárate, Late Quaternary eolian records of the Americas and their paleoclimatic significance. In: V. Markgraf, Editor, Interhemispheric Climate Linkages, Academic Press, San Diego (2001), pp. 183-216.

Muhs et al., $1996<$ D. R. Muhs, T. W. Stafford, S. D. Cowherd, S. A. Mahan, R. Kihl, P. B. Maat, C. A. Bush and J. Nehring, Origin of the Late Quaternary dune fields of northeastern Colorado, Geomorphology 17 (1996), pp. 129-149.

Muhs et al., 1997a $\varangle$ D. R. Muhs, T. W. Stafford, J. Been, S. A. Mahan, J. Burdett, G. Skipp and Z. M. Rowland, Holocene eolian activity in the Minot dune field, North Dakota, Canadian Journal of Earth Sciences 34 (1997), pp. 1442-1459.

Muhs et al., 1997b $<$ D. R. Muhs, T. W. Stafford, J. B. Swinehart, S. D. Cowherd, S. A. Mahan, C. A. Bush, R. F. Madole and P. B. Maat, Late Holocene eolian activity in the mineralogically mature Nebraska Sand Hills, Quaternary Research 48 (1997), pp. 162-176.

National Map, 20094 National Map, Data Available from U. S. Geological Survey, EROS Data Center, Sioux Falls, SD (2009).

Oglesby and Erickson, $1989<$ R. J. Oglesby and D. J. Erickson, Soil moisture and the persistence of North American drought, Journal of Climate 2 (1989), pp. 1362-1380.

Olson et al., $1997 \varangle$ C. G. Olson, W. D. Nettleton, D. A. Porter and B. R. Brasher, Middle Holocene Aeolian activity on the high plains of west-central Kansas, The Holocene 7 (1997), pp. 255-261.

Reeves, 19654 C. C. Reeves, Chronology of west Texas pluvial lake dunes, Journal of Geology 73 (1965), pp. 504-508.

Rubin and Ikeda, $1990<$ D. M. Rubin and H. Ikeda, Flume experiments on the alignment of transverse, oblique, and longitudinal dunes in directionally varying flows, Sedimentology 37 (1990), pp. 673-684.

Sarnthein, $19784 \mathrm{M}$. Sarnthein, Sand deserts during glacial maximum and climatic optimum, Nature 272 (1978), pp. 43-46.

Smith, 19654 H. T. U. Smith, Dune morphology and chronology in central and western Nebraska, Journal of Geology 73 (1965), pp. 557-578.

Sridhar et al., 20064 V. Sridhar, D. B. Loope, J. B. Swinehart, J. A. Mason, R. J. Oglesby and C. M. Rowe, Large wind shift on the Great Plains during the medieval warm period, Science 313 (2006), pp. 345-347.

Stokes and Swinehart, 19974 S. Stokes and J. B. Swinehart, Middleand late-Holocene dune reactivation in the Nebraska sand Hills, USA, The Holocene 7 (1997), pp. 263-272.

Sun and Muhs, $2007 \varangle$ J. Sun and D. R. Muhs, Dune fields: mid-latitudes. In: S. A. Elias, Editor, Encyclopedia of Quaternary Sciences, Elsevier, Amsterdam (2007), pp. 607-626.

Swinehart, 19984 J. B. Swinehart, Wind-blown deposits. In: A. S. Bleed and C. A. Flowerday, Editors, An Atlas of the Sand Hills, University of Nebraska-Lincoln, Lincoln (1998), pp. 43-56.

Wang et al., $2007 \varangle$ C. Wang, S. -K. Lee and D. B. Enfield, Impact of the Atlantic warm pool on the summer climate of the Western Hemisphere, Journal of Climate 20 (2007), pp. 5021-5040.

Warren, 1976 A. Warren, Morphology and sediments of the Nebraska Sand Hills in relation to Pleistocene winds and the development of Aeolian bedforms, Journal of Geology 84 (1976), pp. 685-700.

Watts and Wright, $1966 \varangle$ W. A. Watts and H. E. Wright Jr., Late-Wisconsin pollen and seed analysis from the Nebraska sand Hills, Ecology 47 (1966), pp. 202-210.

Wells, 1983 G. L. Wells, Late-glacial circulation over central North America revealed by Aeolian features. In: A. Street-Perrott, M. Beran and R. Ratcliffe, Editors, Variations in the Global Water Budget, D. Reidel, Dordrecht (1983), pp. 317-330.

Wolfe et al., $2001<$ S. A. Wolfe, D. J. Huntley, P. P. David, J. Ollerhead, D. J. Sauchyn and G. M. MacDonald, Late 18th century drought-induced sand dune activity, Great Sand Hills, Saskatchewan, Canadian Journal of Earth Sciences 38 (2001), pp. 105-117. 